\title{
Indium rich InGaN solar cells grown by MOCVD
}

\author{
H. Çakmak • Engin Arslan • M. Rudziński • \\ P. Demirel · H. E. Unalan • W. Strupiński • \\ R. Turan · M. Öztürk • E. Özbay
}

Received: 18 March 2014/ Accepted: 2 June 2014/Published online: 11 June 2014

(c) Springer Science+Business Media New York 2014

\begin{abstract}
This study focuses on both epitaxial growths of $\mathrm{In}_{\mathrm{x}} \mathrm{Ga}_{1-\mathrm{x}} \mathrm{N}$ epilayers with graded In content, and the performance of solar cells structures grown on sapphire substrate by using metal organic chemical vapor deposition. The high resolution X-ray and Hall Effect characterization were carried out after epitaxial InGaN solar cell structures growth. The In content of the graded InGaN layer was calculated from the X-ray reciprocal space mapping measurements. Indium contents of the graded InGaN epilayers change from 8.8 to $7.1 \%$ in Sample A, $15.7-7.1 \%$ in Sample B, and $26.6-15.1 \%$ in Sample C. The current
\end{abstract}

H. Çakmak $(\bowtie) \cdot$ E. Arslan · P. Demirel · E. Özbay

Nanotechnology Research Center, Bilkent University, 06800 Bilkent, Ankara, Turkey

e-mail: hcakmak@bilkent.edu.tr

M. Rudziński · W. Strupiński

Institute of Electronic Materials Technology, 01-919 Warsaw, Poland

H. E. Unalan

Department of Metallurgical and Materials Engineering, Middle

East Technical University, 06800 Ankara, Turkey

R. Turan

Department of Physics, Middle East Technical University, 06800 Ankara, Turkey

M. Öztürk

Department of Physics, Faculty of Science and Arts, Gazi

University, Teknikokullar, 06500 Ankara, Turkey

E. Özbay

Department of Physics, Bilkent University,

06800 Bilkent, Ankara, Turkey

E. Özbay

Department of Electrical and Electronics Engineering, Bilkent University, 06800 Bilkent, Ankara, Turkey voltage measurements of the solar cell devices were carried out after a standard micro fabrication procedure. Sample B exhibits better performance with a short-circuit current density of $6 \mathrm{~mA} / \mathrm{cm}^{2}$, open-circuit voltage of $0.25 \mathrm{~V}$, fill factor of $39.13 \%$, and the best efficiency measured under a standard solar simulator with one-sun air mass 1.5 global light sources $\left(100 \mathrm{~mW} / \mathrm{cm}^{2}\right)$ at room temperature for finished devices was $0.66 \%$.

\section{Introduction}

An increasing demand for energy observed over the past 50 years has necessitated research on clean and commercially viable energy resources. Predictions show that the worldwide energy consumption will increase from 13 TW (2011) to approximately $30 \mathrm{TW}$ by 2050 [1]. Therefore, solar energy is a vast, easily accessible and safe source of energy.

III-Nitrides are proven to be an excellent system of materials suitable for optoelectronic devices. While high efficiency light-emitting diodes and lasers [2] have already been introduced, many of the properties of the said material system remain unknown and, therefore, are of interest in photovoltaics [3].

$\mathrm{In}_{\mathrm{x}} \mathrm{Ga}_{1-\mathrm{x}} \mathrm{N}$ solar cell structures have the potential to cover $90 \%$ of the solar spectrum thanks to the band gaps of indium nitride $(\mathrm{InN})$ and gallium nitride $(\mathrm{GaN})$ ranging between 0.7 and $3.4 \mathrm{eV}$, respectively. Photovoltaic devices that have a band gap larger than $2.0 \mathrm{eV}$ have gained a lot of attention since half of the photons in the solar spectrum belong there. One of the highest solar cell conversion efficiency obtained by Guter et al. using standard triple junction gallium indium phosphide (GaInP), gallium arsenide (GaAs), and germanium (Ge) [4] is exceeding $41 \%$. 
These structures have band gaps of $1.9,1.4$, and $0.7 \mathrm{eV}$, respectively [5]. A further increase in efficiency requires additional junctions. Theoretically, a four junction solar cell can reach an efficiency of approx. $62 \%$ with the band gaps $0.6,1.11,1.69$, and $2.48 \mathrm{eV}$ [6]. However, increasing the number of junction's poses difficulties in finding a suitable material with proper band gaps, which could be lattice-matched to the rest of the junctions. Fortunately, IIInitride alloys offer great potential to overcome this problem. Nevertheless, only a partial success has been achieved in terms of increasing the amount of $\mathrm{In}$ in $\operatorname{In}_{\mathrm{x}} \mathrm{Ga}_{1-\mathrm{x}} \mathrm{N}$ epitaxial layers, aimed at covering the whole possible range and, at the same time, preserving the high quality of grown epilayers. It is mainly due to the fact that these materials are well-known but still have to be developed.

The purpose of this work is to present the results for an In rich InGaN solar cell epitaxial structure obtained by using metal organic chemical vapor deposition (MOCVD). The material characterizations and performance of solar cell devices was carried out after a standard micro fabrication procedure and included X-ray diffraction, Hall Effect, and current voltage measurements.

\section{Experimental procedure}

In this work, the growth of epitaxial layers was performed by the AIXTRON 200/4 RF-S MOCVD system. TMGa, TMIn, TEGa, $\mathrm{NH}_{3}, \mathrm{SiH}_{4}$, and $\mathrm{Cp}_{2} \mathrm{Mg}$ were used as material sources and hydrogen and nitrogen were used as carrier gasses. Before each growth run, c-plane sapphire substrates were heated to $1,100{ }^{\circ} \mathrm{C}$ for $10 \mathrm{~min}$ in order to subsequently clean them under $\mathrm{H}_{2}$ flow for $10 \mathrm{~min}$. Epitaxial growths started with a $\mathrm{GaN}$ nucleation layer (NL) at a relatively low temperature continue with a $\mathrm{GaN}$ buffer and n-doped $\mathrm{GaN}$ layer using an $\mathrm{SiH}_{4}$ source. The total GaN thin film thickness was approx. $1.5 \mu \mathrm{m}$ for all solar cell structures. In order to complete the $\mathrm{n}-\mathrm{i}-\mathrm{p}$ junction, $\mathrm{p}-\mathrm{In}$ $\mathrm{GaN}$ layers were used with an In composition of $7 \%$ and a thickness of $30 \mathrm{~nm}$. The solar cell structures shown in Fig. 1 have different compositionally graded active $\mathrm{In}_{\mathrm{x} 1 \rightarrow \mathrm{x} 2} \mathrm{GaN}$ layers. Indium contents of graded $\mathrm{InGaN}$ epilayers change from 8.8 to $7.1 \%$ in Sample A, 15.7 to $7.1 \%$ in Sample B, and 26.6 to $15.1 \%$ in Sample C. In order to tune In content in graded InGaN epilayers for Sample A, B, and C, both growth temperatures and V/III ratios were varied.

Before device fabrication, solar cell structures were annealed at $550{ }^{\circ} \mathrm{C}$ for 15 min under a $\mathrm{N}_{2}$ ambient for $\mathrm{Mg}$ activation. $\mathrm{Mg}$ activation temperature for the $\mathrm{p}$-InGaN layers was lower than for typical $\mathrm{p}-\mathrm{GaN}$ to avoid lattice rearrangement in the $\operatorname{In}_{\mathrm{x}} \mathrm{Ga}_{1-\mathrm{x}} \mathrm{N}$ layers. To expose the $\mathrm{n}$-GaN for $\mathrm{n}$-contact, a mesa structure was formed using an
ICP-RIE etching system. The n-ohmic contact was formed by depositing $\mathrm{Ti} / \mathrm{Al} / \mathrm{Ni} / \mathrm{Au} \quad(20 / 100 / 40 / 100 \mathrm{~nm})$ and annealing at $750{ }^{\circ} \mathrm{C}$ in forming gas ambient $\left(5 \% \mathrm{H}_{2} / 95 \%\right.$ Ar) for $90 \mathrm{~s}$. Then, Ni/Au $(40 / 150 \mathrm{~nm})$ layers were deposited on $\mathrm{p}-\mathrm{GaN}$ to form p-contact metal schemes by an electron-beam evaporation system and then annealed at $650{ }^{\circ} \mathrm{C}$ in forming gas ambient $\left(5 \% \mathrm{H}_{2} / 95 \% \mathrm{Ar}\right)$ for $60 \mathrm{~s}$.

Schemes of both the $\operatorname{In}_{\mathrm{x}} \mathrm{Ga}_{1-\mathrm{x}} \mathrm{N}$ solar cell structures and a fabricated device are shown in Fig. 1. The SEM image showed that thicknesses of InGaN epilayers are approximately $148 \mathrm{~nm}$ (Fig. 2).

All the grown epilayers were characterized by a Rigaku SmartLab High resolution X-ray (HR-XRD) diffractometer with a rotating $\mathrm{Cu}$ anode $\left(\mathrm{K}_{\alpha}=1.544 \AA\right)$. The electrical properties were measured using an ECOPIA HMS-3000 Hall Effect measurement system, with a magnetic field

\section{(a)}

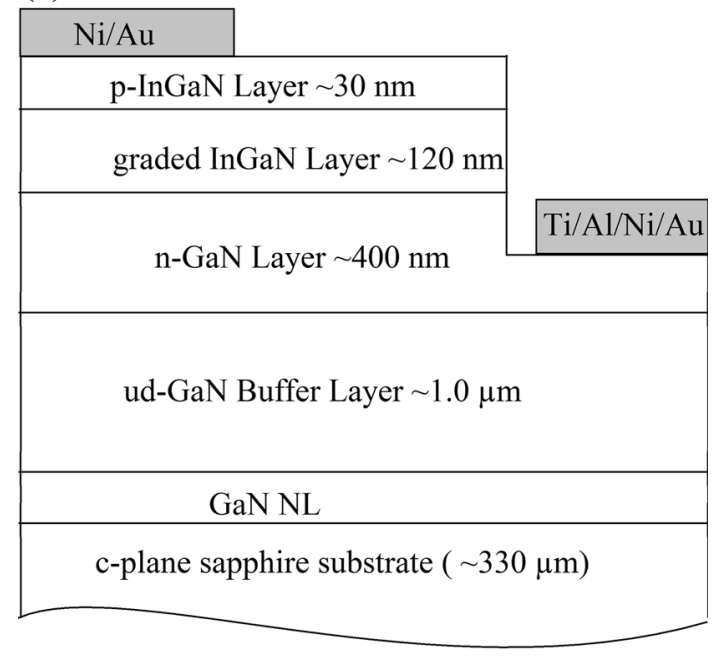

(b)

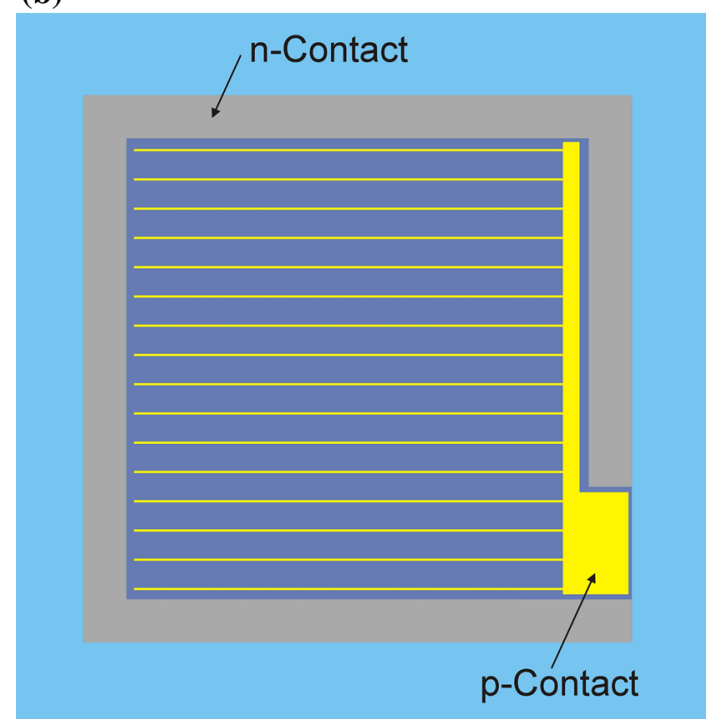

Fig. 1 Schemes of a solar cell structures, and $\mathbf{b}$ solar cell device 


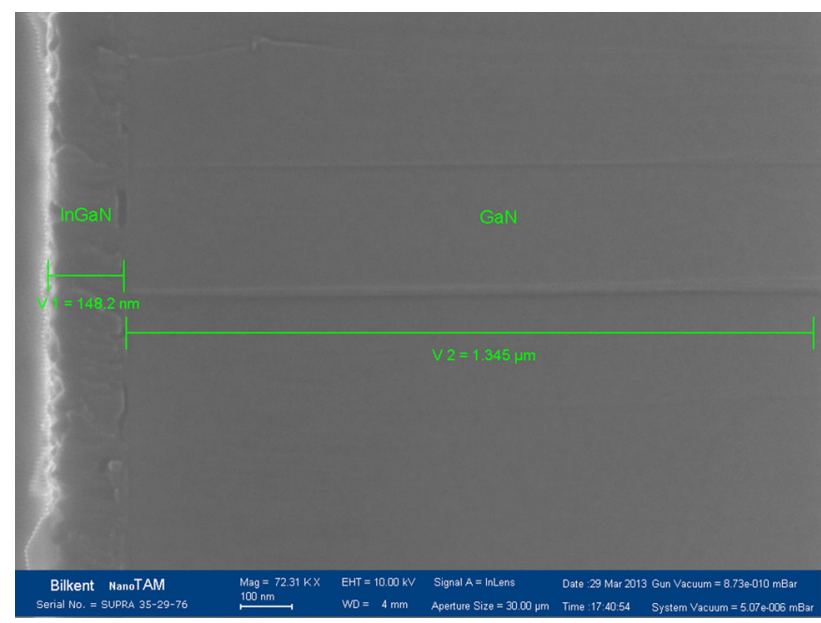

Fig. 2 SEM images of the solar cell structure (sample B)

strength of $0.57 \mathrm{~T}$. The atomic force microscopy (AFM) VEECO CPII contact mode was used to monitor the surface quality of the epilayers. The I-V characteristics of the fabricated solar cells were measured by a semiconductor device analyzer (Agilent Technologies, B1500 A) under a standard solar simulator with a one-sun air mass (AM) 1.5 global light sources $\left(100 \mathrm{~mW} / \mathrm{cm}^{2}\right)$ at room temperature. The solar simulator was calibrated before the measurements using a standard solar cell.

\section{Results and discussion}

To some extent, the degradation of the surface quality of the $\mathrm{In}_{\mathrm{x}} \mathrm{Ga}_{1-\mathrm{x}} \mathrm{N}$ epilayers presented in the AFM images (Fig. 3) is also correlated with the deterioration of the structural quality. Strained InGaN epilayers show higher roughness, which decreases with increasing growth temperature [8]. A gradual change of the growth mode from step-flow growth to three-dimensional island growth was related with lower adatom surface mobility at lower growth temperatures. Lowering the adatom surface mobility increases the surface roughness [9]. The AFM images that are shown in Fig. 3 exhibit similar roughness where Sample A has a roughness value of $23.33 \mathrm{~nm}$, Sample B is $13.49 \mathrm{~nm}$, and Sample $\mathrm{C}$ is $30.10 \mathrm{~nm}$. The rough surface of the solar cell structures arises from lower growth temperatures.

The effect of growth temperature on growth modes was also observed by Young Huang et al. [7]. The structural quality of $\mathrm{In}_{\mathrm{x}} \mathrm{Ga}_{1-\mathrm{x}} \mathrm{N}$ (In, in the range $40-80 \%$ ) is deteriorated after three-dimensional growth, which is not the case for In-rich $\operatorname{In}_{x} \mathrm{Ga}_{1-\mathrm{x}} \mathrm{N}$ and $\mathrm{InN}$. For the latter layers, we observe a much lower broadening, even though their

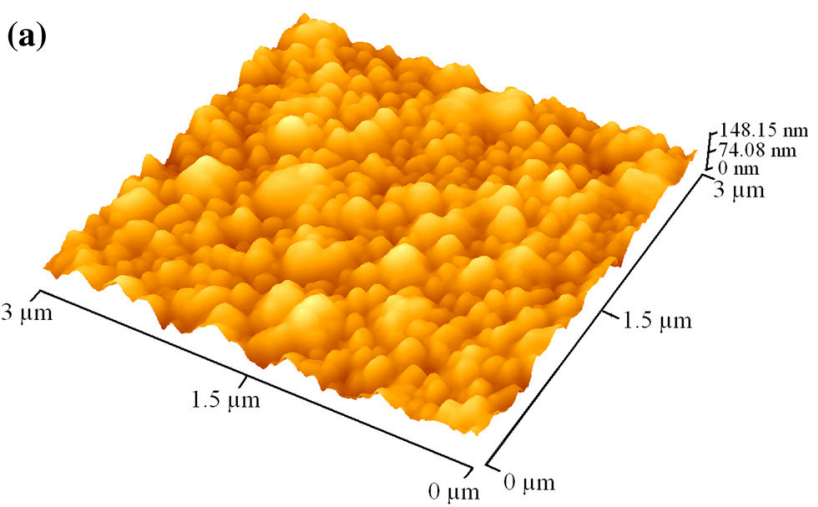

(b)
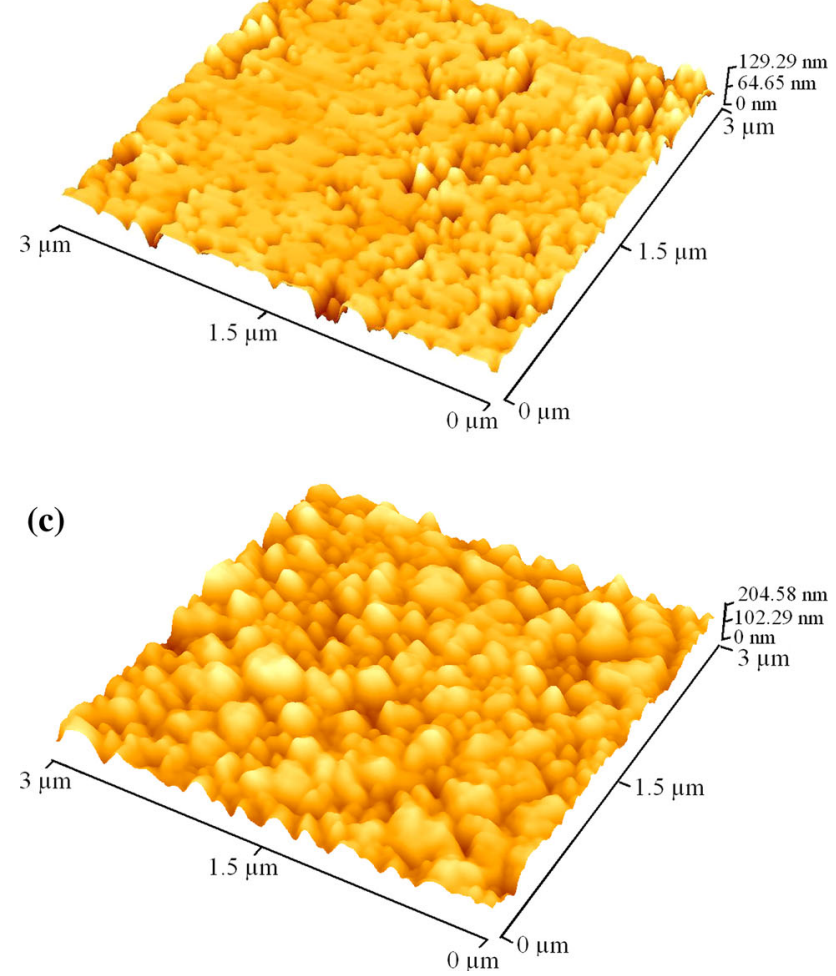

Fig. $3 \mathrm{AFM} 3 \times 3 \mu^{2}$ images of the InGaN solar cell structures a sample $\mathrm{A}$, b sample $\mathrm{B}$, and $\mathbf{c}$ sample $\mathrm{C}$

surface roughness is the highest. Here, a much better crystallographic order of islands must be grown, and can be the main reason accounting for higher mobility for these layers. This additionally shows that the structural quality, and more specifically a better crystallographic order, is the factor influencing mobility to a much higher extent than the background electron concentration.

HR-XRD measurements were performed for all of the samples in order to investigate the crystal phase of the InGaN layers on a GaN buffer layer. The $\omega-2 \theta$ scan of the (0002) reflection for all solar cell samples are shown in Fig. 4, as the spectra of $\operatorname{In}_{\mathrm{x}} \mathrm{Ga}_{1-\mathrm{x}} \mathrm{N}$ layers, in which In 


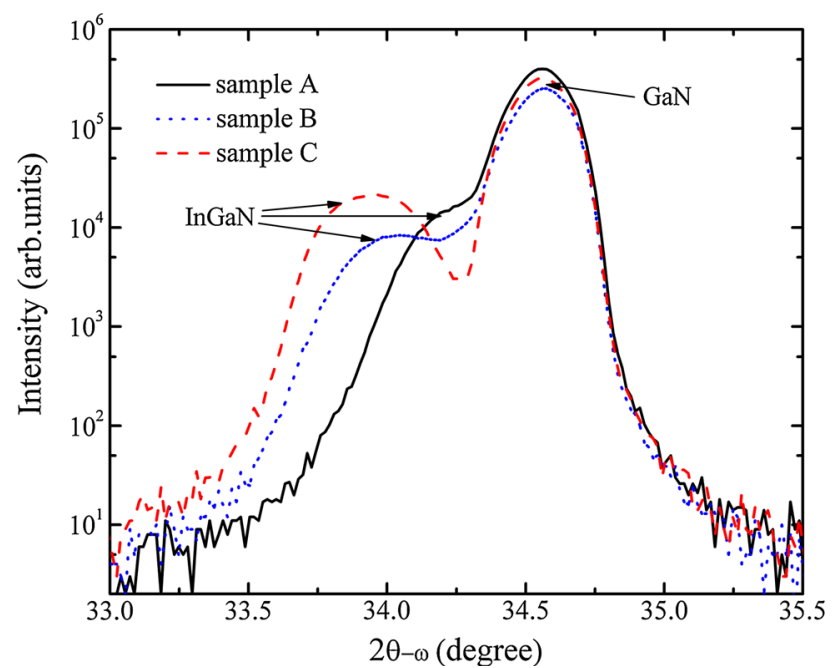

Fig. 4 HR-XRD $2 \theta-\omega$ scan of the (0002) reflections for all samples

composition changes in a wide range. The diffraction patterns exhibited the wurtzite InGaN epilayers with graded indium concentration are clearly observed. Also from Fig. 4, the (0002) peaks of the wurtzite GaN template layers are shown at similar angle values at 34.56. The structural characterization of imperfect crystalline layers can be made in a detailed way by using HRXRD reciprocal-space X-ray mapping (RSM) [10-12].

In the RSM study, in the perpendicular direction (i.e. $2 \theta-\omega$-scan) and in the parallel direction along the diffraction vectors (i.e. $\omega$-scan) scans were done. Correspondingly, a map taken from an asymmetric reflection of the samples allows one to deduce both the in-plane (a) and the out-of-plane (c) lattice parameters, and thus to simultaneously determine the residual strain and stress as well as the exact alloy composition of the layers [10-12].

The lattice parameters $a$ and $c$ can be determined directly from the $h k l$ reflections in the symmetric $\omega-2 \theta$ scan by combining Bragg's equation $d_{h k l}=n \lambda / 2 \sin (\theta)$, where $(h k l)$ is the Miller index in $(h k-(h+k) l)$ notation, $\lambda$ is the wavelength of the $\mathrm{X}$-rays and $\theta$ is the Bragg angle, with the expression for interplanar spacing in hexagonal structures given below [10,11]

$d_{h k l}=\frac{1}{\sqrt{\frac{4}{3} \frac{h^{2}+k^{2}+h k}{a^{2}}+\frac{l^{2}}{c^{2}}}}$

In order to calculate $d_{h, k, l}$ values by using Eq. (1) at least two reflections' measurements are needed [because of two unknowns $(a$ and $c)$ ]. Generally, one or two high-angle symmetric reflections are measured from the (0002) and/or (0004) planes, from which $c$ can be found directly [10]. On the other hand, the $a$ values can be calculated with just one or two high-angle asymmetric reflection measurements [typically (10-15), (20-25) or (20-24) reflection]. From high-angle asymmetric reflections $a$ values can be determined by combining the value of $c$ found previously [10]. If the material is assumed to be unstrained, then the composition is the only factor affecting the lattice parameters and only the lattice parameters need to be measured. For this case, Vegard's law applies, which states that the lattice parameters of an alloy will vary linearly between the end members $[10,12]$. In content of the unstrained materials can be calculated by using Vegard's law. However, in the strained case, real Indium content $(\mathrm{x})$ in the InGaN layers can be calculated from the RSM measurements around symmetric (0002) and asymmetric (10-15) reflections. More detailed information about the calculations can be found in Ref. [10]. The calculated In content values are shown in Table 1.

The RSM for both symmetric (0002) and asymmetric (10-15) reflections of the solar cell structures was performed. The measured results are given for symmetric (0002) reflections in Fig. 5 and for asymmetric (10-15) reflections in Fig. 6, respectively.

As can be seen in Figs. 5 and 6, for both symmetric (0002) and asymmetric (10-15) reflections, we see large spreading in the InGaN peak values because of the In gradient in InGaN layers. The In content of the solar cell structures were calculated from the RSM values. The calculated In contents are shown in Table 1 . As can be seen in Table 1, the In content of the sample A changes between 8.8 and $7.1 \%$ but, on the other hand, in sample B the In content changes between 15.7 and $7.1 \%$ and for Sample C the In content gradient found between 26.6 and $15.1 \%$.

We carried out room-temperature low field Hall Effect measurements where the carrier concentrations and mobilities are $2.8 \times 10^{18} \mathrm{~cm}^{-3}$ and $272 \mathrm{~cm}^{2} /$ Vs for Sample A, $4.6 \times 10^{18} \mathrm{~cm}^{-3}$ and $244 \mathrm{~cm}^{2} / \mathrm{Vs}$ for Sample B, and $3.3 \times 10^{18} \mathrm{~cm}^{-3}$ and $217 \mathrm{~cm}^{2} /$ Vs for Sample C.

The electrical performance of the solar cells was determined by performing current density versus voltage $(J-V)$ measurements under a standard solar simulator with a one-sun air mass (AM) 1.5 global light source $(100 \mathrm{~mW} /$ $\mathrm{cm}^{2}$ ) at room temperature using a semiconductor device analyzer (Agilent Technologies, B1500 A). The results obtained in dark and illuminated conditions, for a different In composition are shown in Fig. 7a-c. The area of the fabricated solar cell was $1 \mathrm{~mm}^{2}$, including the metal contact pads.

From the $\mathrm{J}-V$ characteristics, solar cell parameters such as fill factor $(\mathrm{FF})$, series resistance $\left(\mathrm{R}_{\mathrm{s}}\right)$, shunt resistance $\left(\mathrm{R}_{\mathrm{sh}}\right)$, and efficiency $(\eta)$ were calculated and tabulated in Table 1. As shown in Table 1, Sample B exhibits better performance with a short-circuit current density $\left(\mathrm{J}_{\mathrm{sc}}\right)$ of $6 \mathrm{~mA} / \mathrm{cm}^{2}$, open-circuit voltage $\left(\mathrm{V}_{\mathrm{oc}}\right)$ of $0.25 \mathrm{~V}$, fill factor 
Table 1 Measured solar cells parameters such as, AFM roughness (RMS), low field Hall mobility $(\mu)$, carrier density $\left(\mathrm{N}_{H}\right)$, ideality factor (n), fill factor $(F F)$, series resistance $\left(R_{s}\right)$, shunt resistance $\left(R_{s h}\right)$ and efficiency $(\eta)$ for all samples

\begin{tabular}{|c|c|c|c|c|c|c|c|c|c|}
\hline $\begin{array}{l}\text { Sample } \\
\text { Id. }\end{array}$ & $\begin{array}{l}\text { Graded in } \\
\text { range }(\%)\end{array}$ & $\begin{array}{l}\text { Roughness } \\
\text { (RMS) } \\
\quad(\mathrm{nm})\end{array}$ & $\begin{array}{l}\text { Hall } \\
\text { mobility } \\
\mu\left(\mathrm{cm}^{2} /\right. \\
\text { Vs })\end{array}$ & $\begin{array}{l}\text { Carrier } \\
\text { density } \\
\mathrm{N}_{\mathrm{H}} \times 10^{18} \\
\left(\mathrm{~cm}^{-3}\right)\end{array}$ & $\begin{array}{l}\text { Ideality } \\
\text { factor }(n)\end{array}$ & $\begin{array}{l}\text { Fill factor } \\
(\mathrm{FF}) \\
(\%)\end{array}$ & $\begin{array}{l}\text { Serises resistance } \\
\left(\mathrm{R}_{\mathrm{s}}\right)(\Omega)\end{array}$ & $\begin{array}{l}\text { Shunt } \\
\text { resistance } \\
\mathrm{R}_{\mathrm{sh}}(\Omega)\end{array}$ & $\begin{array}{l}\text { Efficiency } \\
(\eta)(\%)\end{array}$ \\
\hline$\underset{\text { A }}{\text { Sample }}$ & $8.8 \rightarrow 7.1$ & 23.33 & 272 & 2.9 & 8.94 & 35.30 & 227 & $4.9 \times 10^{3}$ & 0.41 \\
\hline $\begin{array}{l}\text { Sample } \\
\text { B }\end{array}$ & $15.7 \rightarrow 7.1$ & 13.49 & 244 & 4.6 & 10.21 & 39.13 & 136 & $9.1 \times 10^{2}$ & 0.66 \\
\hline $\begin{array}{l}\text { Sample } \\
\text { C }\end{array}$ & $26.6 \rightarrow 15.1$ & 30.10 & 217 & 3.3 & 9.56 & 30.35 & 74 & $7.3 \times 10^{3}$ & 0.26 \\
\hline
\end{tabular}

Fig. 5 HR-XRD reciprocal space-maps of the (0002) reflection for solar cell structures, a sample A, b sample $\mathrm{B}$, and $\mathbf{c}$ sample $\mathrm{C}$
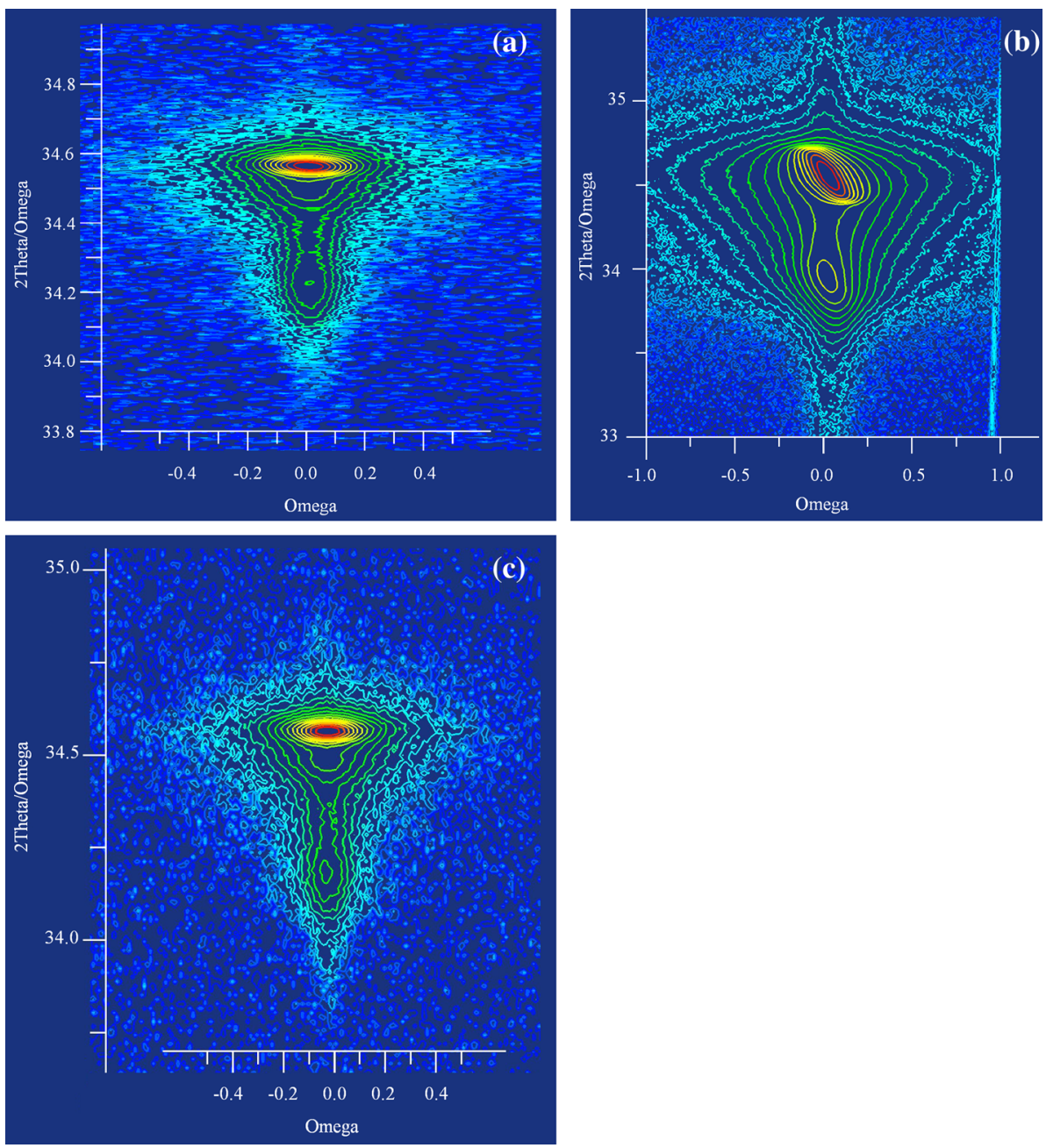
Fig. 6 HR-XRD reciprocal space-maps of the (10-15) reflection for solar cell structures, a sample A, b sample $\mathrm{B}$, and c sample $\mathrm{C}$
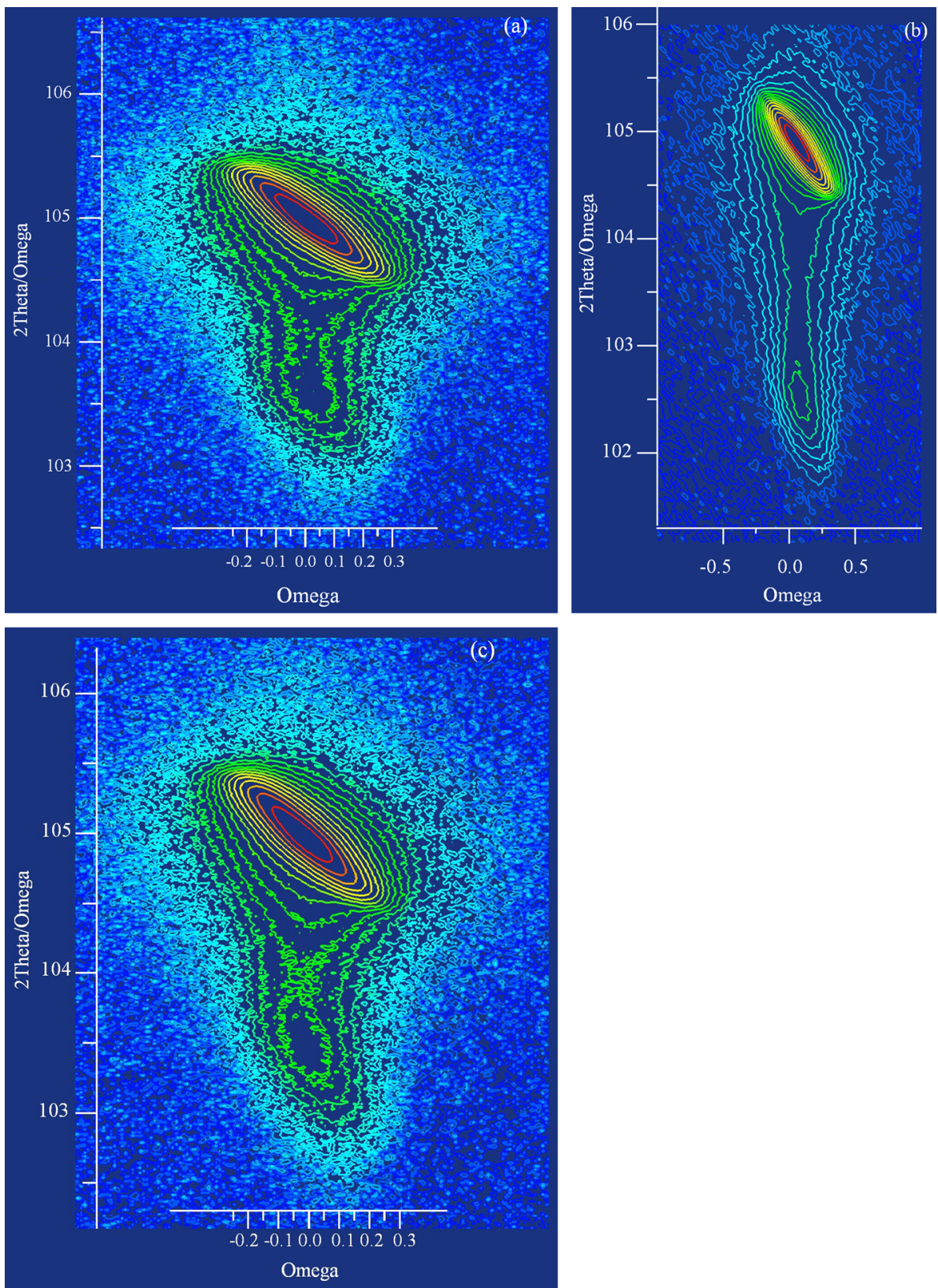
(a)
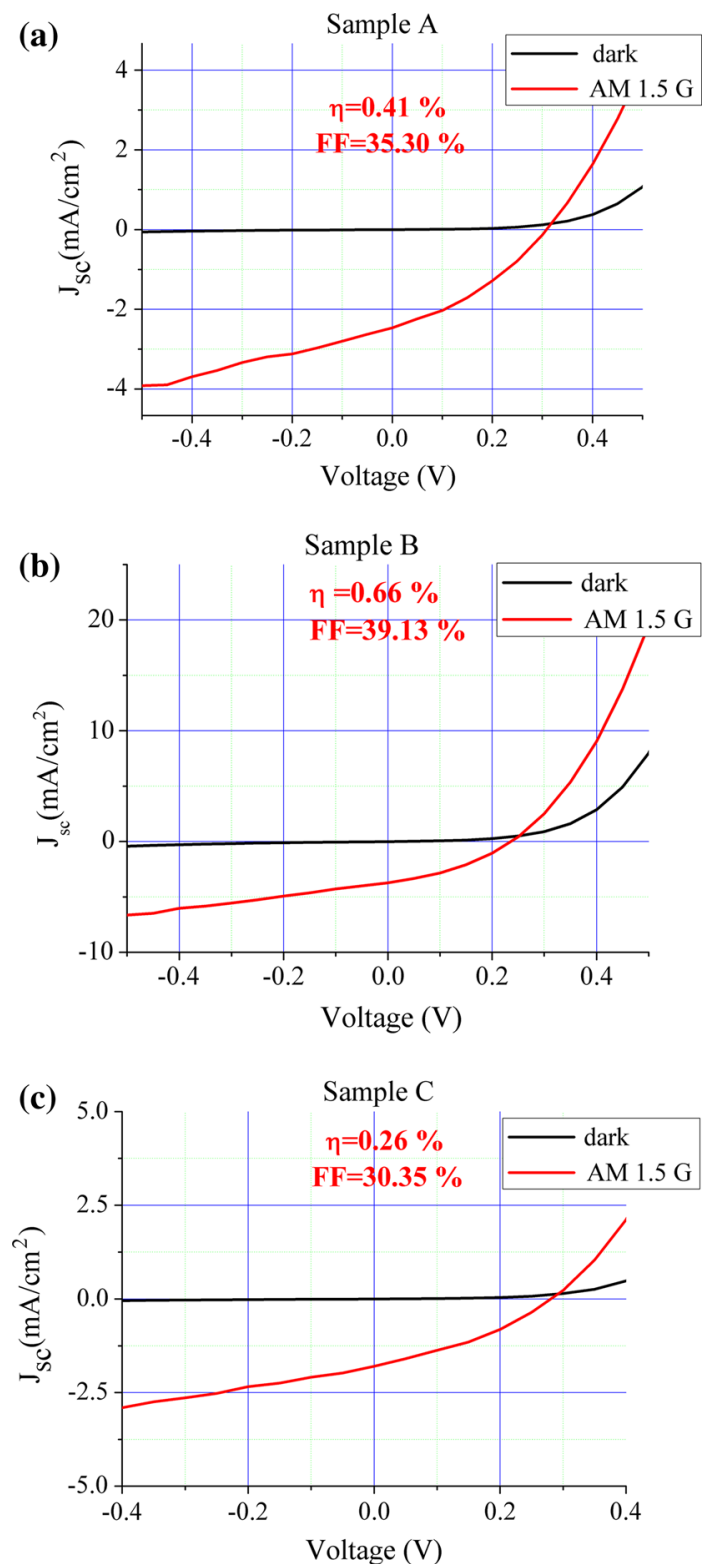

Fig. 7 I-V characteristics of the solar cells with a differently graded In composition of a sample $\mathrm{A}$, $\mathbf{b}$ sample $\mathrm{B}$, c sample $\mathrm{C}$

\section{Conclusion}

The structural quality and the electrical performance of the $\mathrm{In}_{\mathrm{x}} \mathrm{Ga}_{1-\mathrm{x}} \mathrm{N}$ solar cells structures with graded In content were investigated. In the study, three InGaN solar cell structures were used. In the InGaN layers, the grade values changed between 8.8 and $7.1 \%$ in Sample A, 15.7-7.1\% in Sample B, and 26.6-15.1\% in Sample C. The current voltage measurements of the solar cell devices were carried out after a standard micro fabrication procedure. Sample B exhibits better performance with a short-circuit current density of $6 \mathrm{~mA} / \mathrm{cm}^{2}$, open-circuit voltage of $0.25 \mathrm{~V}$, fill factor of $39.13 \%$, and the best efficiency measured under a standard solar simulator with one-sun air mass 1.5 global light sources $\left(100 \mathrm{~mW} / \mathrm{cm}^{2}\right)$ at room temperature for finished devices was $0.66 \%$.

Acknowledgments This work is supported by the projects DPTHAMIT, DPT-FOTON, NATO-SET-193 and TUBITAK under Project Nos. 113E331, 109A015 and 109E301. One of the authors (E.O.) also acknowledges partial support from the Turkish Academy of Sciences.

\section{References}

1. M.I. Hoffert, K. Caldeira, A.K. Jain, E.F. Haites, L.D. Harvey, S.D. Potter, M.E. Schlesinger, T.M.L. Wigley, D.J. Wuebbles, Nature 881, 395 (1998)

2. S. Nakamura, G. Fasol, The Blue Laser Diode (Springer, Berlin, 1997)

3. O. Jani, I. Ferguson, C. Honsberg, S. Kurtz, Appl. Phys. Lett. 91, 132117 (2007)

4. W. Guter, J. Schöne, S.P. Philipps, M. Steiner, G. Siefer, A. Wekkeli, E. Welser, E. Oliva, A.W. Bett, F. Dimroth, Appl. Phys. Lett. 94, 223504 (2009)

5. W. Junqiao, J. Appl. Phys. 106, 011101 (2009)

6. O. Jani, Development of Wide-Band Gap InGaN Solar Cells for High-Efficiency Photovoltaics (Georgia Institute of Technology, Georgia, 2008)

7. Y. Huang, B. Jampana, M. Jamil, J.-H. Ryou, R.D. Dupuis, I.T. Ferguson, J. Photon. Energy 2, 028501-1 (2012)

8. H. Wang, D.S. Jiang, U. Jahn, J.J. Zhu, D.G. Zhao, Z.S. Liu, S.M. Zhang, Y.X. Qiu, H. Yang, Phys. B 405, 4668-4672 (2010)

9. F.K. Yam, Z. Hassan, InGaN: an overview of the growth kinetics, physical properties and emission mechanisms. Superlattices Microstruct. 43, 1-23 (2008)

10. M.A. Moram, M.E. Vickers, Rep. Prog. Phys. 72, 036502 (2009)

11. P.F. Fewster, Crit. Rev. Solid State Mater. Sci. 22, 69 (1997)

12. E. Arslan, M.K. Ozturk, H. Çakmak, P. Demirel, S. Özçelik, E. Ozbay, J. Mater. Sci. Mater. Electron. 24, 4471 (2013)

13. K. Mayes, A. Yasan, R. McClintock, D. Shiell, S.R. Darvish, P. Kung, M. Razeghi, Appl. Phys. Lett. 84, 7 (2004)

14. L. Wang, M.I. Nathan, T.H. Lim, M.A. Khan, Q. Chen, Appl. Phys. Lett. 68, 9 (1996)

15. O. Jani, P. Mahala, S.K. Behura, A. Ray, C. Dhanavantri, The effect of indium composition on open-circuit voltage of InGaN thin-film solar cell: an analytical and computer simulation study. AIP Conf. Proc. 1451, 85 (2012)

16. C.L. Reynolds Jr, A. Patel, J. Appl. Phys. 103, 086102 (2008)

17. Engin Arslan, Şemsettin Altındal, Süleyman Özçelik, Ekmel Ozbay, J. Appl. Phys. 105, 023705 (2009)

18. L. Sang, M. Liao, N. Ikeda, Y. Koida, M. Sumiya, Appl. Phys. Lett. 99, 161109 (2011) 